\title{
Pemanfaatan Tepung Kulit Bawang Merah (Allium ascalonicum) Sebagai Imbuhan Pakan Terhadap Penampilan, Profil Darah Dan Kolesterol Pada Puyuh Petelur
}

\section{Utilization of Powdery Skin of Onion (Allium ascalonicum) as Affixes Feed Against the Appearance of Blood and Cholesterol Profiles, on Lay-ing Quail}

\author{
Valerianus Teru*, M. Halim Natsir, Eko Widodo \\ Fakultas Petrenakan Universitas Brawijaya
}

Submitted : 28 July 2017, Accepted : 31 Octoberr 2017

\begin{abstract}
ABSTRAK: Kandungan senyawa aktif flavonoid dalam tepung KBM yang berfungsi sebagai anti bakteri dan anti kolesterol. Puyuh merupakan jenis unggas yang menghasilkan sumber protein hewani. Telur puyuh memiliki kadar kolesterol dua kali lebih tinggi $(844 \mathrm{~g} / \mathrm{dL})$ dibandingkan telur ayam (423 $\mathrm{mg} / \mathrm{dL}$ ), namun dengan kandungan gizi yang lebih baik daripada susu sapi segar. Penelitian ini bertujuan untuk mengetahui efek penambahan tepung KBM dalam pakan terhadap profil darah dan kolesterol telur puyuh. Penelitian ini menggunakan 144 ekor burung puyuh dibagi dalam 4 perlakuan dengan 6 ulangan dan masing-masing diisi 6 ekor puyuh selama 3 bulan. Perlakuan yang diberikan adalah $0 \%, 1 \%, 2 \%, 3 \%$. Berdasarkan perhitungan ANOVA, kuning telur puyuh yang diberi pakan tambahan tepung KBM 3\% menunjukkan penurunan kadar kolesterol $(682.20 \pm 5.30 \mathrm{mg} / \mathrm{dL})$. Parameter profil darah yang diukur adalah jumlah eritrosit dan kadar hemoglobin,. Hasil penelitian menunjukkan jumlah eritrosit dengan nilai $12,870 \pm 3,218$ dan hemoglobin dengan nilai $14,425 \pm 0,842$ tidak nyata $(\mathrm{P}<0,05)$ dipengaruhi oleh perlakuan. Meskipun secara statistik parameter pengamatan akibat perlakuan tidak memberikan hasil yang berbeda nyata, namun jika dilihat dari rerata hasil penelitian menunjukkan bahwa $2 \%$ tepung KBM (P3) dalam pakan memberikan hasil yang terbaik terhadap profil darah.. Sehingga $2 \%$ tepung KBM (P2) dalam pakan dapat dijadikan sebagai feed additive herbal alternative sebagai pengganti antibiotic. Hasil penelitian menunjukkan bahwa tepung KBM mampu menurunkan kolesterol telur puyuh.
\end{abstract}

Kata kunci : Flavonoid, Profil Darah, Tepung Kulit Bawang Merah, Kolestero Telur Puyuh

\begin{abstract}
The main bioactive compound in skin Allium ascalonicum is quercetin, which serves as antibacterial and anticholesterol agent. The purpose of this research was to investigate the effect of skin Allium ascalonicum powder supplementation on blood profile and egg cholesterol content of quail. One hundred and forty-four quails were randomly allocated in 24 flocks, consisting 4 treatments and 6 replications. Each replication consisted of 6 quails. The treatments used were P0: basal diet (control), P1: basal diet $+1 \%$ skin powder Allium ascalonicum, P2: basal diet $+2 \%$ skin of Allium ascalonicum powder, and P3: basal diet $+3 \%$ skin of Allium ascalonicum powder. Variables observed were blood erythrocytes, hemoglobin and egg cholesterol content. Data were analyzed using one-way Analysis of Variance (ANOVA). Significant data was then further analyzed using Duncan Multiple Range Test. The result showed that there was no significant effect $(\mathrm{P}>0.05)$ of shallot skin powder on blood erythrocytes and hemoglobin of quail.There was significant effect $(\mathrm{P}<0.05)$ of skin Allium ascalonicum powder supplementation on egg cholesterol content. Supplementation of skin Allium ascalonicum powder at the level of 3\% (P3) could decrease egg cholesterol content compared to control $(682.20 \mathrm{mg} / \mathrm{dL}$ vs $729.80 \mathrm{mg} / \mathrm{dL})$. The conclusion of this research is that skin of Allium ascalonicum powder supplementation could decrease cholesterol content in quail egg.
\end{abstract}

Keywords: Flavonoids, Blood Profiles, Onion Skin, Cholesterol, Quail

*. Corresponding author: Valenteru1981@gmail.com 


\section{PENDAHULUAN}

Populasi puyuh yang meningkat dari tahun ke tahun membuktikan bahwa puyuh merupakan salah satu komoditi unggas yang semakin populer di masyarakat (Ditjen Peternakan dan Kesehatan Hewan, 2012). Bertambahnya populasi unggas puyuh mengindikasikan banyaknya masyarakat yang berminat untuk memelihara puyuh dan mengonsumsi produk-produk yang dihasilkan dari burung puyuh, khususnya daging dan telur yang memiliki banyak kandungan gizi.

Puyuh pada periode starter (DOQ) umur 1-21 hari memerlukan penanganan yang khusus, terutama pada umur 1-4 hari karena pada periode ini tubuhnya masih lemah dan fungsi-fungsi tubuhnya kurang optimal serta harus adaptasi dengan kandang yang baru karena baru dipindahkan dari mesin tetas ke kandang periode starter (Subekti dan Hastuti, 2013). Terkadang banyak peternak yang mengalami kerugian pada saat pemeliharaan puyuh periode starter dikarenakan tingkat mortalitas yang tinggi. Ada beberapa faktor yang mempengaruhi kondisi fisiologis dari puyuh, diantaranya faktor genetik dan lingkungan. Faktor genetik biasanya bawaan dari induknya, sedangkan faktor lingkungan berasal dari suhu, temperatur, pakan, dan keadaan lingkungan kandang (Listyowati, 2004). Upaya untuk menjaga performa puyuh selama periode starter adalah dengan meningkatkan kekebalan tubuh puyuh. Salah satunya dengan pemberian alternatif berupa herbal yang bermanfaat sebagai antioksidan dan antibakteri.

Kulit bawang merah (KBM) merupakan tanaman fitobiotik yang dapat digunakan sebagai feed aditif pada unggas khususnya puyuh petelur. Hasil peneitian ini menunjukan bahwa kandungan senyawa aktif kulit bawang merah yaitu flavonoid, antioksidan, allisin, pektin, dan fitosterol. Penelitian lain melaporkan bahwa hasil uji fitokimia senyawa aktif tepung kulit bawang merah mengandung flavonoid, terpenoid, fenol yang dapat berfungsi sebagai antibakteri dan sebagai feed additive herbal alternatif pengganti antibiotik dapat ditinjau dari kondisi fisiologis puyuh, diantaranya profil darah dan kolesterol (Razak, 2006).

\section{MATERI DAN METODE}

\section{Lokasi dan waktu}

Penelitian dilakukan di Desa Salamrejo-Blitar, Laboratorium Farmasi Uneir Surabaya, Laboratorium Mipa Unpad Bandung dan Laboratorium Nutrisi FTP Brawijaya Malang. Materi Penelitian sebagai bahan percobaan digunakan 144 ekor puyuh umur 14 hari dan dipelihara selama 12 minggu. Penelitian ini menggunakan ransum komersil dengan kandungan zat nutrisi pakan basal dan kebutuhan nutrisi puyuh dapat dilihat pada Tabel 1 dan Tabel 2.

Tabel 1. Kandungan Nutrisi Pakan Basal Puyuh Petelur

\begin{tabular}{lc}
\hline \multicolumn{1}{c}{ Zat nutrisi } & Kandungan $\mathbf{( \% )}$ \\
\hline Bahan Kering & 10,14 \\
Protein Kasar & 20,32 \\
Lemak Kasar & 3,92 \\
Serat Kasar & 3,50 \\
Abu & 10,06 \\
Calsium & 2,6 \\
Sodium & 0,16 \\
Phospor & 0,67 \\
\hline
\end{tabular}

Sumber : Laboratorium pakan PT. Japfa Comfeed Indonesia

Tabel 2. Kebutuhan Nutrisi Puyuh Petelur

\begin{tabular}{lc}
\hline \multicolumn{1}{c}{ Zat nutrisi } & Kandungan (\%) \\
\hline Bahan Kering & 14,00 \\
Protein Kasar & 17,00 \\
Lemak Kasar & 7,00 \\
Serat Kasar & 7,00 \\
Abu & 14,00 \\
Calsium & $2,50-3,50$ \\
Phospor & 0,40 \\
\hline
\end{tabular}

Sumber: Dinas Peternakan Jawa Timur (2003) 
Metode penelitian yang digunakan adalah Rancangan Acak Lengkap (RAL), dengan 4 perlakuan dan 6 ulangan, dimana setiap perlakuan terdiri dari 6 ekor puyuh. Perlakuan yang diberikan pada puyuh sebagi berikut :

$$
\begin{aligned}
& \text { P0 }=\text { Pakan basal (kontrol) } \\
& \text { P1 }=\text { Pakan Basal }+ \text { Tepung KBM 1\% } \\
& \text { P2 }=\text { Pakan Basal }+ \text { Tepung KBM 2\% } \\
& \text { P3 = Pakan Basal + Tepung KBM 3\% }
\end{aligned}
$$

\section{Pembuatan tepung kulit bawang me- rah}

Sebanyak 3 kg KBM diperoleh dari limbah pembuangan hasil pertanian bawang di Flores. Kulit bawang merah dikeringkan selama 2 hari kemudian dihaluskan atau di giling di Materia Medica Batu Malang. Selanjutnya dilakukan proses pengayakan dengan tujuan menghasilkan tepung yang lebih halus. Sisa pengayakan tersebut kemudian digiling kembali untuk menghasilkan tepung yang lebih halus. Untuk memperoleh $1 \mathrm{~kg}$ kulit bawang merah maka dibutuhkan 17$18 \mathrm{~kg}$ bawang merah dalam bentuk segar.

Peubah yang diamati adalah profil darah yang meliputi eritrosit, hemoglobin dan kolesterol. Data yang diperoleh akan dianalisis dengan menggunakan ANOVA. Jika terdapat perbedaan yang signifikan maka dilanjutkan dengan uji jarak berganda Duncan's.

\section{Tahap sampling darah}

Pengambilan sampel darah dilakukan pada hari terakhir pemeliharaan puyuh periode layer (umur 12 minggu). Sebelum dilakukan sampling darah, puyuh dipuasakan terlebih dahulu selama 24 jam (Jayanti, 2011). Darah diambil dari jantung sebanyak 2 cc menggunakan syringe. Sebelumnya, daerah dada puyuh dibersihkan dengan menggunakan alkohol $70 \%$, bila daerah tersebut berbulu dihilangkan terlebih dahulu menggunakan gunting. Sampel darah dimasukkan dalam tabung yang diisi dengan antikoagulan (heparin). Tabung darah tersebut disim- pan dalam termos es yang telah diberi es batu ataupun tanpa es.

\section{Analisis darah}

\section{a. Perhitungan Jumlah Eritrosit}

Perhitungan jumlah sel darah merah dilakukan dengan alat kamar hitung sel darah merah menggunakan mikroskop dengan pembesaran 100 kali. Prosedur pengerjaannya adalah aspirator dipasang pada pipet sel darah merah. Darah yang telah dihisap sampai batas angka 0,5 pada pipet, ujung pipetnya dibersihkan menggunakan tisu. Larutan Hayem dihisap sampai tanda 101 yang tertera pada pipet secara hati-hati. Pada pengisapan ini hindari adanya gelembung, jika terdapat gelembung maka prosedur harus diulang. Selanjutnya aspirator dilepas dari pipet sel darah merah. Dengan menggunakan ibu jari dan telunjuk kanan, isi pipet dihomogenkan selama 3 menit. Bagian yang tidak ikut terkocok harus dibuang. Selanjutnya dengan hati-hati cairan dimasukkan dalam kamar hitung dengan cara menempelkan ujung pipet pada pertemuan antara dasar kamar hitung dan kaca penutup. Butir-butir darah dibiarkan mengendap selama kurang lebih 1 menit. Perhitungan butir darah merah tersebut dilakukan menggunakan hand counter. Untuk menghitung sel darah merah dalam hemocytometer, digunakan kotak sel darah merah yang berjumlah 25 buah dengan mengambil bagian bagian sebagai berikut: satu kotak pojok kanan atas, satu kotak pojok kiri atas, satu kotak tengah, satu kotak pojok kanan bawah, dan satu kotak pojok kiri bawah. Untuk membedakan kotak sel darah merah dengan kotak sel darah putih, dapat berpatokan pada tiga baris pemisah pada kotak sel darah merah dan luas kotak sel darah merah relative kecil dibandingkan dengan kotak leukosit. Butir darah merah yang telah dihitung tersebut disimbolkan dengan a dan untuk mengetahui jumlah sel darah merah dalam $1 \mathrm{~mm} 3$ darah dihi- 
tung dengan menggunakan persamaan 1 (Sastradipraja et.al, 2000).

\section{b. Perhitungan kadar hemoglobin (Hb)}

Metode yang digunakan untuk mengukur kadar haemoglobin adalah metode Sahli. Larutan $\mathrm{HCl}$ 0,01 N diteteskan pada tabung Sahli sampai tanda tera 0,1 atau garis bawah, kemudian sampel darah dihisap menggunakan pipet hingga mencapai tanda tera atas. Sampel darah segera dimasukkan ke dalam tabung dan ditunggu selama 3 menit atau hingga berubah warna menjadi coklat kehitaman akibat reaksi antara HCL dengan haemoglobin membentuk asam hematin. Larutan ditambah dengan aquades, diteteskan sedikit sambil terus diaduk. Larutan aquades ditambahkan hingga warna larutan sama dengan warna standard hemoglobinometer. Nilai haemoglobin di kolom "gram\%" yang tertera pada tabung haemoglobin, yang berarti banyaknya haemoglobin dalam gram $100 \mathrm{ml}$ darah (Sastradipraja et al., 2000).

\section{Kadar kolesterol kuning telur}

Pengukuran kadar kolesterol dengan menggunakan Spektrofotometer (U.S Interdepartmental Committee on Nutrition for National Defense, 1963). Kuning telur ditimbang sebesar $0.1 \mathrm{~g}$ dan $0.1 \mathrm{ml}$ akuades sebagai blanko. Tambahkan $1 \mathrm{ml}$ alkoholoic $\mathrm{KOH} \mathrm{33 \%} \mathrm{dan}$ diaduk terus sampai terjadi gumpalan. Simpan di waterbath $390-400{ }^{\circ} \mathrm{C}$ selama 1 jam, setelah itu ditambahkan $4 \mathrm{ml} \mathrm{PE}$ 400-600 ${ }^{\circ} \mathrm{C}$, untuk deret standar ditambahkan $2 \mathrm{ml}$ PE. Selanjutnya ditambahkan $0.25 \mathrm{ml} \mathrm{H}_{2} \mathrm{O}$, kocok selama 1 menit, kemudian dibuka, dan ditutup lagi untuk di sentrifuse. Standar dan contoh $200 \mu 1$ diambil dengan menggunakan pipet dan ditambahkan batu didih. Simpan di waterbath $800^{\circ} \mathrm{C}$ selama 2 menit kemudian dikeringkan menggunakan oven $1050-1100^{\circ} \mathrm{C}$ selama 35 menit, dinginkan pada suhu kamar. Tambahkan $4 \mathrm{ml}$ acetic-sulfuric acid, kocok dan diamkan 35 menit, lalu baca dengan spektro-fotometer pada panjang gelombang $630 \mathrm{~nm}$.

Kolesterol kuning telur

$=\frac{(\text { Abs contoh }- \text { Abd blk } \times \text { rata }- \text { rata } \times 4 / 2)}{\text { gram contoh }}$

\section{HASIL DAN PEMBAHASAN}

Darah merupakan komponen penting dalam tubuh. Darah adalah jaringan yang bersirkulasi melalui pembuluh darah, membawa zat-zat penting untuk kehidupan selama sel tubuh dan menerima produk buangan hasil metabolisme untuk dibawa ke organ sekresi. Gambaran darah ternak akan mengalami perubahan seiring dengan perubahan fisiologisnya. Perubahan fisiologis secara internal dapat disebabkan seperti pertambahan umur, status gizi, latihan, kesehatan, stress, siklus reproduksi, dan suhu tubuh, sedangkan secara eksternal akibat kuman dan perubahan suhu lingkungan. Darah dalam tubuh dibagi menjadi tiga yaitu sel darah merah (eritrosit), sel darah putih (leukosit), dan trombosit. Darah dapat dijadikan sebagai indikasi adanya gangguan fisiologi dalam tubuh ternak karena darah berperan sebagai media homeostasis (Jayanti, 2011).

Penggunaan tepung KBM pada pakan puyuh selama fase pemeliharaan tidak berpengaruh nyata $(\mathrm{P}>0,05)$ terhadap eritrosit dan hemoglobin burung puyuh. Data profil darah selengkapnya disajikan pada Tabel 3, terlihat bahwa profil darah puyuh selama penelitian setiap perlakuan menunjukkan respon nilai yang sama. 
Tabel 3. Rataan Kadar Hemoglobin, Jumlah Eritrosit dan Total Kolesterol Telur Puyuh Periode Finisher pada Perlakuan Penambahan Tepung Kulit Bawang Merah

\begin{tabular}{lcccc}
\hline \multirow{2}{*}{\multicolumn{1}{c}{ Variabel }} & \multicolumn{4}{c}{ Perlakuan } \\
\cline { 2 - 5 } & P0 & P1 & P2 & P3 \\
\hline Eritrosit (juta $\left.\mathrm{mm}^{-3}\right)$ & $2.910 \pm 0.385$ & $2.929 \pm 0.326$ & $3.218 \pm 0,264$ & $3.090 \pm 0,213$ \\
Hemoglobin $(\mathrm{g} \%)$ & $12.675 \pm 2.281$ & $13.225 \pm 1.179$ & $14.425 \pm 0.842$ & $13.900 \pm 0.993$ \\
Total Kolesterol & $729.80 \pm 1.47^{\mathrm{a}}$ & $719.52 \pm 1.01^{\mathrm{b}}$ & $692.18 \pm 0.92^{\mathrm{c}}$ & $682.20 \pm 5.30^{\mathrm{d}}$ \\
(mg/dL) & & & & \\
\hline
\end{tabular}

Keterangan : superskrip yang berbeda pada kolong yang sama menunjukkan perbedaan yang nyata $(\mathrm{P}<0,05)$.

\section{Eritrosit}

Eritrosit (sel darah merah) pada unggas yang mempunyai nukleus, dan berperan membawa hemoglobin dengan mengikat oksigen ke seluruh tubuh. Rataan jumlah eritrosit puyuh pada penelitian ini (Tabel 2) berkisar antara 2.910-3.218 juta/mm3. Hasil analisis statistik menunjukkan bahwa penggunaan tepung KBM dalam pakan puyuh tidak berpengaruh nyata $(\mathrm{P}>0,05)$ terhadap rataan jumlah eritrosit puyuh. Jumlah eritrosit puyuh pada semua perlakuan berada di bawah kisaran normal yaitu 3,86 juta/mm3. Jumlah eritrosit ini dipengaruhi oleh umur, jenis kelamin, hormon, hipoksia (kekurangan oksigen), aktivitas, nutrisi, produksi telur, bangsa, suhu lingkungan dan faktor iklim.

Penambahan tepung KBM dalam pakan puyuh belum secara optimal membantu meningkatan sirkulasi darah dalam memperbaiki aktivitas jaringan tubuh. Hal ini disebabkan pemberian tepung KBM dalam pakan puyuh dilakukan hanya pada periode starter dimana pada periode tersebut puyuh masih dalam masa perkembangan sehingga pembentukan eritrosit belum maksimal. Dengan bertambahnya umur puyuh maka jumlah eritrosit juga akan meningkat, namun terlihat adanya peningkatan jumlah eritrosit dengan adanya penambahan tepung KBM dalam pakan puyuh. Jumlah eritrosit yang paling tinggi terlihat pada puyuh perlakuan P2 yaitu yang mendapat 2\% tepung KBM dalam pakan puyuh jika dibandingkan dengan perlakuan yang lainnya.

\section{Hemoglobin}

Hemoglobin adalah senyawa yang berasal dari ikatan komplek antara protein dan Fe yang menyebabkan timbulnya warna merah pada darah. Hemoglobin merupakan komponen dari eritrosit dan hematokrit. Fungsi dari hemogloin ini adalah untuk mengikat oksigen. Rataan kadar hemoglobin puyuh terlampir pada Tabel 2. Berdasarkan analisis statistik menunjukkan bahwa perlakuan tidak berbeda nyata $(\mathrm{P}<0,05)$ terhadap kadar hemoglobin. Rataan kadar hemoglobin puyuh pada penelitian ini berkisar antara 14,425-12,675 g\%, yang berada ada kisaran yang tidak jauh dari normal. Kadar hemoglobin normal puyuh adalah 12,3 g\%. Perlakuan R2 (2\% tepung KBM dalam pakan puyuh) masih dalam keadaan normal, sedangkan untuk perlakuan $\mathrm{P} 0$, P1 (1\% tepung KBM dalam pakan puyuh) dan P3 (3\% tepung KBM dalam pakan puyuh) kadar hemoglobinnya sedikit dibawah kisaran normal karena puyuh masih dalam masa perkembangan. Hal ini menunjukkan bahwa penambahan tepung KBM dalam pakan puyuh tidak menganggu kadar hemoglobin puyuh, karena adanya kandungan mineral Fe pada kulit bawang merah yang merupakan pembentuk molekul hemoglobin Bahkan penggunaan 2 tepung KBM mampu meningkatkan kadar hemoglobin sekitar 2,8\%, jika dibandingkan dengan R0 se- 
bagai kontrol yang menggunakan antibiotic.

\section{Kolesterol}

Kolesterol pada telur dapat ditemui pada kuning telur dimana kolesterol merupakan komponen lemak yang berfungsi untuk sintesis asam empedu, prekusor hormon steroid dalam tubuh dan sintesis vitamin D (Gordon, 1985; Fore, 1988; Ruxton et al., 2010). Kandungan kolesterol pada kuning telur terendah sebesar $682.20 \pm 5.30 \mathrm{mg} / \mathrm{dL}$ dihasilkan pada pakan perlakuan P3 (penambahan $3 \%$ tepung $\mathrm{KBM}$ ), dimana terjadi penurunan sebesar $0,065 \%$ apabila dibandingkan dengan pakan kontrol walaupun secara statistik tidak ada perbedaan antar perlakuan. Semakin tinggi kandungan tepung KBM dalam pakan maka kandungan kolesterol kuning telur juga akan menurun jika dibandingkan dengan pakan kontrol Rendahnya kadar kolesterol dalam kuning telur ini pada P3 dapat disebabkan karena adanya kandungan serat kasar yang tinggi pada tepung KBM. Serat kasar ini akan mempercepat laju pakan (transit time) mengikat asam empedu yang sangat diperlukan dalam penyerapan lemak sehingga absorpsi lemak terhambat dan meningkatkan ekskresi lemak termasuk kolesterol melalui feses. Serat kasar memiliki sifat mengikat bahan organik lain, misalnya asam empedu yang kemudian akan terbuang bersama feses. Asam empedu berfungsi memecah lemak hingga terurai menjadi asam lemak yang akan diserap tubuh (Saraswati et al., 2013). Adanya serat makanan yang mengikat asam empedu mengakibatkan jumlah asam empedu bebas akan berkurang sehingga akan dibutuhkan asam empedu baru. Asam empedu baru dibentuk dari kolesterol yang ada dalam darah sehingga kolesterol dalam darah akan menurun.

Kolesterol sangat dibutuhkan oleh tubuh hewan sebagai komponen struktural dan fungsional sel. Kolesterol berfungsi sebagai bahan untuk sintesis hormon steroid, unsur garam empedu, dan prekursor sintesis kuning telur (vitelogenin) Meer et al., 2008; Bhat dan Bhat, 2015). Vitelogenin disintesis di hati yang dikemas dalam bentuk VLDL (Very Low Density Lipoprotein), kemudian di transfer ke dalam ovarium dan diakumulasikan dalam folikel sebagai kuning telur (Salvante et al., 2007). Oleh karena itu, Piliang dan Djojosoebagio (2008) mengemukakan pemberian pakan yang kandungan serat kasarnya tinggi pada unggas dapat menurunkan kadar kolesterol darah dan kuning telur. Estrogen pada puyuh petelur berfungsi untuk perkembangan folikel, sehingga apabila folikel yang berkembang banyak, maka materi pembentuk yolk seperti kolesterol akan terdistribusi secara menyebar ke seluruh folikel, sehingga kadar kolesterol telur dapat berkurang. Estrogen berfungsi sebagai hormon perangsang biosintesis vitelogenin di hati. Vitelogenin adalah suatu protein yang menjadi bahan pembentuk kuning telur. Vitelogenin yang telah disintesis di dalam hati selanjutnya masuk ke peredaran darah dan diserap oleh sitoplasma oosit (da Silva et al., 2008). Selain itu, diduga penurunan kadar kolesterol total kuning telur puyuh disebabkan karena semakin banyak hierarki folikel yang berkembang pada puyuh yang diberi pakan tambahan tepung KBM, sehingga kolesterol yang merupakan salah satu komponen penyusun kuning telur akan terdistribusi ke sejumlah folikel yang telah berkembang, yang mengakibatkan penurunan kadar kolesterol telur puyuh (Saraswati,2013)

\section{KESIMPULAN}

Hasil penelitian ini menunjukan bahwa perlakuan dengan penambahan tepung kulit bawang merah 3\% dapat menurunkan kadar kolesterol pada kuning telur puyuh tetapi tidak berpengaruh pada jumlah eritrosit dan jumlah hemoglobin pada darah burung puyuh. 
DAFTAR PUSTAKA

Bhat, Z, F, Bhat, H, F. 2015. Bioactive pep-tides from egg: a review. $\mathrm{Nu}-$ trition \& Food Science. 45(2):190-212

Jayanti, A. M. 2011. Pengaruh Konsumsi Pakan Protein dan Min eral Besi (Fe) terhadap Profil Darah Puyuh

Jayanti, A. M. 2011. Pengaruh Konsumsi Pakan Protein dan Mineral Besi (Fe) terhadap Profil Darah Puyuh yang Diberi Tepung Daun Katuk dan Murbei Dalam Pakan. S Fakultas Peternakan. Institus Pertanian Bogor.

Listyowati, E. 2004. Tata Laksana Budidaya Puyuh Secara Komersil. Penebar Swadaya, Jakarta.

Piliang, W, G, Djojosoebagio, S, A, H. 2008. Fisiologi Nutrisi. IPB Press, Bogor.

Razak, R. A. 2006. Kolesterol Berlebihan Resiko Sakit Jantung. http://www.bharian.commy/m/Bh arian/Saturday/BeritaSawit/2006090 2120309/Article/Diakses tanggal tanggal 21 Maret 2013.

Ruxton, C, H, S, Derbyshire, E, Gibson, S. 2010. The nutritional proper ties and health benefits of eggs. Nutrition \& Food Science. 40(3).263-279

Salvante, K, G, Lin, G, Walzem, R, L, Wil-liams, T, D. 2007. Characte rization of very-low density lipoprotein particle diameter dy namics in relation to egg production in a passerine bird. J. Exp. Biol. 210(6):1064-1074
Saraswati, T, R, Manalu, W, Ekastuti, D, R, Kusumorini, N. 2013. The role of tur-meric powder in lipid metabolism and its effect on quality of the first quail's egg. J. Indonesian Trop. Anim. Agric. 38(2):123-130

Sturkie, P. D. dan P. Griminger. 1976. Blod : physical characteristics, formed elements, hemoglobin and coagulation. Dalam: Sturkie, P. D. (Editor). Avian Physiology. $3^{\text {rd }}$ Edition. Springer-Verlag New York, Inc,Heidelberg, Berlin.

Subekti, E., dan D. Hastuti. 2013. Budidaya Puyuh (Coturnix coturnix japonica) di Pekarangan Sebagai Sumber Protein Hewani dan Penambah Income Keluarga. Mediagro Vol. 9, No. 1 : 1-10 